\title{
Hormonal and developmental regulation of the mouse aldose reductase-like gene akr1b7 expression in Leydig cells
}

\author{
S Baron, M Manin, C Aigueperse, M Berger, C Jean, G Veyssière and L Morel \\ UMR CNRS 6547, Physiologie Comparée et Endocrinologie Moléculaire, Université Blaise Pascal, 24 avenue des Landais, 63177 Aubière \\ cedex, France \\ (Requests for offprints should be addressed to L Morel; Email: laurent.morel@univ-bpclermont.fr)
}

\begin{abstract}
The akr1b7 gene encodes an aldose reductase-like protein that is responsible for detoxifying isocaproaldehyde generated by the conversion of cholesterol to pregnenolone. The regulation of gene expression by human chorionic gonadotropin ( $\mathrm{hCG}$ ) was first investigated in the MA-10 Leydig tumor cell line. The akr1b7 gene was constitutively expressed and accumulation of its mRNA was increased in a dose- and time-dependent manner by treatment with hCG. akr1b7 mRNA accumulation was sharply increased in the presence of $0.25 \mathrm{nM}$ hCG and it reached a fivefold increase within $2 \mathrm{~h}$. AKR1B7 protein accumulation was delayed compared with that of the corresponding mRNA. In agreement, hCG significantly increased the levels of mRNA and protein of akr1b7 in primary cultures of adult mouse Leydig cells, thus suggesting that LH potentially regulates akr1b7 gene expression in vivo. Expression of akr1b7 was developmentally regulated in the testis. Unexpectedly, levels of akr1b7 mRNA increased from embryonic day 15 to the day of birth and declined until adulthood while AKR1B7 protein levels followed an inverse pattern, suggesting an important role for translational mechanisms.
\end{abstract}

Journal of Molecular Endocrinology (2003) 31, 71-81

\section{Introduction}

Cholesterol, the essential sterol found in vertebrates, is the substrate for the synthesis of steroid hormones such as mineralocorticoids, glucocorticoids and sex steroids. Steroid hormones, which act as endocrine messengers, are synthesized in the adrenals, gonads, placenta and brain. Steroidogenesis in adrenal and gonadal cells and its regulation by trophic hormones are well documented (Miller 1988, Simpson \& Waterman 1988). The first and rate-limiting step in gonadal and adrenal steroidogenesis is the mobilization of cholesterol from cellular stores to the mitochondrial inner membrane mediated by at least two intracellular molecules: the steroidogenic acute regulatory protein (StAR) and the peripheral-type benzodiazepine receptor (Stocco \& Clark 1997, Papadopoulos 1998). Steroidogenesis begins with the conversion of cholesterol into pregnenolone and isocaproaldehyde (4-methyl pentanal). The reaction is catalyzed by the cytochrome $\mathrm{P} 450$ side-chain cleavage (P450 scc) enzyme which resides in the inner mitochondrial membrane (Privalle et al. 1983). After leaving the mitochondrion, pregnenolone is transferred to endoplasmic reticulum to give rise to several other steroids via different pathways. This process is highly regulated by trophic hormones, such as adrenocorticotropin $(\mathrm{ACTH})$ and gonadotropins, acting via intracellular cAMP and subsequent activation of the protein kinase A (PKA) signaling pathway (Hanukoglu et al. 1990).

Whereas few tissues are able to synthesize steroid hormones, many tissues of the body can metabolize steroids. The aldo-keto reductases (AKRs) are an enzyme superfamily of $\mathrm{NAD}(\mathrm{P}) \mathrm{H}$ oxidoreductases that catalyze the reduction of a wide variety of substrates including aldoses, aliphatic and aromatic aldehydes, ketones, prostaglandins and xenobiotics 
(Jez et al. 1997). The AKR superfamily contains steroid transforming enzymes that play pivotal roles in the inactivation and action of sex steroids. Cluster analysis showed that the first family (AKR1) of the superfamily includes aldehyde reductases (AKR1A), aldose reductases (AKR1B) and the hydroxysteroid dehydrogenases (AKR1C). While the expression and regulation of steroidogenic genes have been studied extensively, those involved in steroid catabolism have not been well characterized. AKR1B7, an aldose reductase-like protein, represents the major secretory component of the mouse vas deferens (Taragnat et al. 1988, Pailhoux et al. 1990). However, this expression profile is restricted to the mouse species (Taragnat et al. 1990). In vivo and in vitro studies have demonstrated that androgens are the major regulator of $a k r 1 b 7$ gene expression in the vas deferens (Martinez et al. 1990, Fabre et al. 1994, Darne et al. 1997). AKR1B7 was shown to be highly expressed in adrenals from various rodents, under the control of pituitary ACTH (Aigueperse et al. 1999) and where it acts as a major reductase for isocaproaldehyde, a harmful aldehyde generated by steroidogenesis (Lefrancois-Martinez et al. 1999). Lately, using proteome analysis, Brockstedt et al. (2000) have identified AKR1B7 as a protein induced by luteinizing hormone $(\mathrm{LH})$ in the murine ovary. All steroidogenic cells catalyze the transformation of cholesterol to pregnenolone and produce isocaproaldehyde. It might be postulated that AKR1B7 is expressed and plays the same detoxifying role in all steroidogenic cells. The objectives of the current study were to determine if Leydig cells express akr $1 b 7$ at mRNA and protein levels under the control of LH/human chorionic gonadotropin (hCG) and to examine the developmental pattern of $a k r 1 b 7$ gene expression in testis.

\section{Materials and methods}

\section{Animals}

Adult mice (Swiss strain CD-1; Charles River, L'arbresle, France) were housed under standard animal housing conditions in accordance with the NIH guide for the care and use of laboratory animals. Female animals were placed in individual cages with males, and the morning on which a vaginal plug was found was designated day 0 (E0) of pregnancy.

\section{Purification of Leydig cells and cell culture}

This purification technique was first described by Lefevre et al. (1983). Briefly, testes from 30-day-old male mice were decapsulated and incubated for $20 \mathrm{~min}$ at $33^{\circ} \mathrm{C}$ in Dulbecco's modified Eagle's medium (DMEM)/Ham's F12 (1:1), transferrin $(5 \mu \mathrm{g} / \mathrm{ml})$, insulin $(4 \mu \mathrm{g} / \mathrm{ml})$ and vitamin $\mathrm{E}(0 \cdot 2 \mu \mathrm{g} /$ $\mathrm{ml})$ medium containing collagenase $(0 \cdot 8 \mathrm{mg} / \mathrm{ml})$ (Life Technologies, Invitrogen, Cergy-Pontoise, France). Crude extracts were collected by centrifugation for $10 \mathrm{~min}$ at $200 \boldsymbol{g}$ and the pellet was resuspended in fresh medium. Following two successive sedimentations, the supernatant containing Leydig cells was centrifuged and the pellet was resuspended in fresh medium at a final concentration of $10^{7}$ cells $/ \mathrm{ml}$. Five milliliters of the suspension was layered on top of a discontinuous Percoll gradient (four layers from 21 to 60\%) prepared from a stock solution (90\% Percoll:10\% Ham's F10 $(10 \times), 20 \mathrm{mM}$ Hepes, $140 \mathrm{mM}$ $\mathrm{NaHCO}_{3}$, pH 7.4) diluted with DMEM/Ham's F12. After centrifugation for $30 \mathrm{~min}$ at $2000 \boldsymbol{g}$ at $4{ }^{\circ} \mathrm{C}$, purified Leydig cells were collected at the 60-34\% layer interface, diluted in fresh medium and washed twice. Cells were seeded in fetal calf serum-pretreated six-well plates $\left(1.8 \times 10^{6}\right.$ cells/ well) in DMEM/Ham's F12 (1:1), transferrin $(5 \mu \mathrm{g} / \mathrm{ml})$, insulin $(4 \mu \mathrm{g} / \mathrm{ml})$ and vitamin $\mathrm{E}(0 \cdot 2 \mu \mathrm{g} /$ $\mathrm{ml}$ ) medium. The medium was changed every $24 \mathrm{~h}$.

Murine MA-10 Leydig tumor cells (Ascoli 1981) were grown in Waymouth's medium (Life Technologies) supplemented with $15 \%$ horse serum, $2 \mathrm{mM}$ L-glutamine, penicillin $(100 \mathrm{U} / \mathrm{ml})$ and streptomycin $(100 \mu \mathrm{g} / \mathrm{ml})$ (Life Technologies). Prior to hormone treatment, cells were cultured for $24 \mathrm{~h}$ in DMEM/Ham's F12 (1:1) medium in the absence of serum. In the experiments involving inhibitors, they were added $1 \mathrm{~h}$ before hormones or activators.

\section{Northern blot analysis}

Total RNA was extracted from MA-10 cells, Leydig cells or testes with TRIzol (Life Technologies) according to the manufacturer's instructions. Total RNA $(30 \mu \mathrm{g})$ was separated in a $1 \%$ (w/v) agarose gel and $2 \cdot 2 \mathrm{M}$ formaldehyde gel and transferred onto Hybond $\mathrm{N}+$ nylon membranes (Amersham Pharmacia Biotech, Orsay, France). The 3'UTR akr1b7 cDNA fragment $(+975 /+1176$ with respect to the numbering of the $a k r 1 b 7 / m v d p$ sequence NM_009731; Genbank), and P450 scc, 
glyceraldehyde 3-phosphate dehydrogenase ( $g a d p h$ ) and $\beta$-actin cDNAs were labeled with the ${ }^{32} \mathrm{P}$-dCTP NEBlot kit (New England Biolabs, Ozyme, Saint-Quentin en Yvelines, France). Prehybridization was carried out for $2 \mathrm{~h}$ at $65{ }^{\circ} \mathrm{C}$ in $3 \times \mathrm{SSC}$, $0 \cdot 2 \%$ PVP, $0 \cdot 2 \%$ Ficoll, $5 \%$ PEG, $1 \%$ glycine, $1 \%$ SDS and $100 \mu \mathrm{g} / \mathrm{ml}$ sonicated salmon sperm DNA. Hybridization was performed overnight in the same solution in the presence of $10^{6}$ c.p.m. $/ \mathrm{ml}$ labeled probes. After washing, blots were exposed to an imaging screen K (BioRad, Marnes-laCoquette, France) and visualized using a BioRad molecular imager FX phospho-imager. Hybridization signals were analyzed using the Quantity One quantification software (BioRad).

\section{RT-PCR}

Equal amounts of total RNA $(2 \mu \mathrm{g})$ were reverse transcribed in the presence of 100 pmol random hexanucleotides using $200 \mathrm{U}$ M-MLV reverse transcriptase (Promega, Charbonnieres, France) according to the manufacturer's instructions. First-strand cDNAs were amplified by PCR using, in combination, $100 \mathrm{pmol}$ specific primers for akr1b7 (5'-TCACTCAGAGAACTCTCTGC-3', 5'-ATCATGCACGGATCTCATCA-3') and gapdh (5'-CATCACGATCTTCGAGGA-3', 5'-CACGA CGTTCTTGATG TG- ${ }^{\prime}$ ) in the presence of $5 \mathrm{U}$ Taq polymerase (Goldstar; Eurogentec, Seraing, Belgium). Equal volumes of PCR products were collected after 15 amplification cycles and analyzed by agarose gel electrophoresis.

\section{Western blot analysis}

A fraction of cell sample was collected before RNA extraction and suspended in $0.25 \mathrm{M}$ Tris- $\mathrm{HCl}$, $\mathrm{pH}$ 7.5. Cells were lysed by sonication. Soluble proteins were recovered by centrifugation $(15 \mathrm{~min}$, $10000 \mathrm{~g}, 4^{\circ} \mathrm{C}$ ) and quantitated by the Bradford method (BioRad). Proteins were subjected to SDS-PAGE on 10\% acrylamide gels and transferred onto nitrocellulose membranes (Amersham Pharmacia Biotech). Non-specific protein-binding sites were blocked by incubation for $1 \mathrm{~h}$ at room temperature in $50 \mathrm{mM}$ Tris- $\mathrm{HCl}, \mathrm{pH} 8,150 \mathrm{mM}$ $\mathrm{NaCl}$ and $0 \cdot 1 \%$ (v:v) Tween 20 (TBS-T) containing $10 \%$ (w:v) non-fat dry milk. Incubation with the polyclonal anti-AKR1B7 L3 antibody (1:3000) (Val et al. 2002) was carried out overnight at $4{ }^{\circ} \mathrm{C}$. After washing in TBS-T, membranes were incubated for $1 \mathrm{~h}$ at room temperature with the peroxidaseconjugated anti-rabbit IgG (1:10 000) (P.A.R.I.S, Compiègne, France). Blots were washed and peroxidase activity detected by autoradiography with the ECL system (Amersham Pharmacia Biotech). Hybridization signals were quantified using the molecular analyst software (BioRad).

\section{Immunolocalization of AKR1B7 in Leydig cell primary cultures}

Cells seeded on coverslips were fixed in the culture well with 95\% methanol and 5\% acetic acid for $8 \mathrm{~min}$, and permeabilized in the presence of phosphate-buffered saline (PBS) and $0 \cdot 1 \%$ Triton for $4 \mathrm{~min}$. Cells were incubated overnight at $4{ }^{\circ} \mathrm{C}$ with the L3 antibody (1:150). After washing in PBS, non-specific protein-binding sites were blocked by incubation with PBS and 5\% goat serum. Incubation with the FITG (fluorescin isothiocyanate) anti-rabbit IgG (1:150) was carried out for $1 \mathrm{~h}$ at room temperature. A negative control was included by replacing the primary antibody with PBS. Cells were washed in PBS and slides were observed under UV irradiation with a photonic microscope (Zeiss, Le Pecq, France).

\section{Chemical localization of $3 \beta$-hydroxysteroid

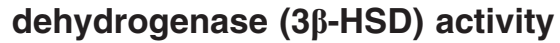

Cells grown on coverslips were incubated for $4 \mathrm{~h}$ in $0.1 \mathrm{M}$ phosphate buffer containing $1.5 \mathrm{mM}$ $\mathrm{NAD}^{+}, 0.25 \mathrm{mM}$ nitro blue tetrazolium, nicotinamide and $0.4 \mathrm{mM} 3 \beta$-hydroxy- $5 \beta$-androstan- $17 \beta$ one, as described previously (Payne et al. 1980).

\section{Results}

\section{hCG induces akr1b7 expression in MA-10 mouse Leydig tumor cells: involvement of the cAMP/PKA pathway}

The biosynthesis of androgens is stimulated through the $\mathrm{LH} / \mathrm{hCG}$ receptor, a G proteincoupled receptor, after coupling to cAMPdependent protein kinases. In order to determine whether LH/hCG can control akr1b7 expression in Leydig cells, Northern blot and Western blot analyses were performed in MA-10 cells stimulated with increasing doses of hCG for $6 \mathrm{~h}$ (Fig. 1A). The pattern of hCG induction of $a k r 1 b 7$ was compared 
A

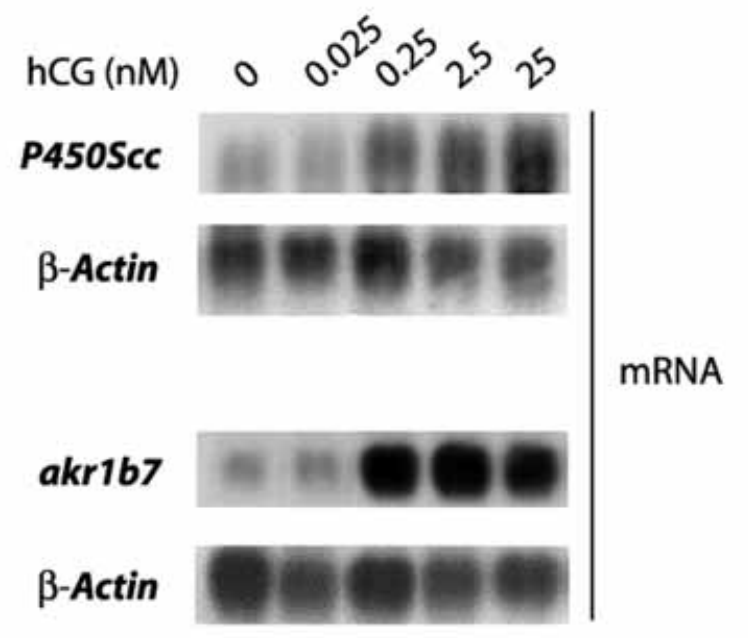

AKR1B7

B

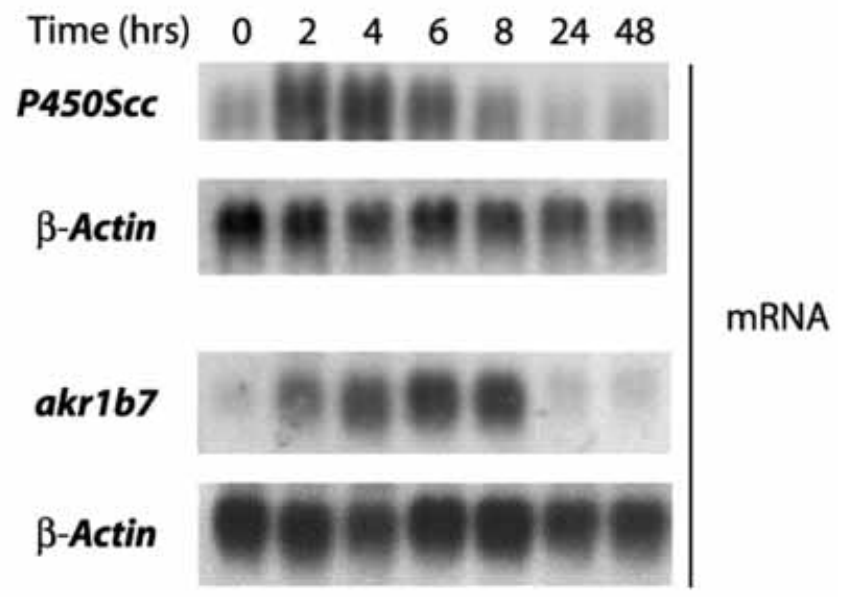

\section{AKR1B7}

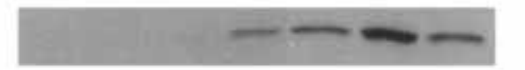

protein

Figure 1 Effects of hCG on P450Scc mRNA levels and akr1b7 mRNA and protein levels in MA-10 cells. MA-10 cells were incubated for $6 \mathrm{~h}$ with increasing concentrations of (A) hCG or (B) with $0.25 \mathrm{nM}$ hCG for 2-48 h. Total cytoplasmic RNAs were isolated as described in Materials and methods, subjected to Northern blot analysis and hybridized sequentially with akr1b7, P450Scc and $\beta$-actin cDNA probes. Total cytoplasmic proteins were isolated as described in Materials and methods, separated by SDS-PAGE migration and subjected to Western blot analysis. Immunodetection was performed with the $L 3$ antibody $\left(1 / 3000^{\mathrm{e}}\right)$. The blots presented are representative of three independent experiments. 
with that of the cholesterol side-chain cleavage enzyme $\mathrm{P} 450$ scc, which is known to be regulated by the LH/hCG hormone and which produces isocaproaldehyde, the best substrate for AKR1B7 (Lefrancois-Martinez et al. 1999). In the absence of hCG, akr1b7 mRNA was expressed at low levels. As observed for P450 scc, hCG significantly increased akr1b7 mRNA levels at a concentration of $0.25 \mathrm{nM}$, and maximal induction was attained with $2 \cdot 5 \mathrm{nM}$ hCG. The action of hCG was time dependent and first detectable after $2 \mathrm{~h}$ of treatment (Fig. 1B). Maximum induction with $0 \cdot 25 \mathrm{nM} \mathrm{hCG}$ was about fivefold after $6 \mathrm{~h}$ and the mRNA levels returned to basal values after $24 \mathrm{~h}$. The kinetics of the hCG regulation of $P 450$ scc followed a similar pattern to that observed for akr1b7. P450 ssc mRNA levels showed a marked increase at 2 and $4 \mathrm{~h}$ and decreased up to $24 \mathrm{~h}$ (Fig. 1B). These patterns were also observed for StAR and P450c17 (data not shown). On the basis of Western blot analysis, treatment of MA-10 cells with increasing concentrations of hCG markedly enhanced the level of AKR1B7 protein relative to that of untreated control cultures (Fig. 1A). However, whereas the first increase in mRNA levels occurred $2 \mathrm{~h}$ after hCG addition, the significant enhancement in protein concentration was detected only at $6 \mathrm{~h}$ (Fig. 1B).

In Leydig cells, expression of steroidogenic enzymes and the cholesterol transporter StAR in response to $\mathrm{LH} / \mathrm{hCG}$ involves the cAMP signaling pathway. To ascertain whether hCG operates through PKA to induce akrlb7 gene expression, MA-10 cells were treated either with forskolin which potentiates cAMP synthesis or with H89, a PKA specific inhibitor. A 6-h induction with $10^{-5} \mathrm{M}$ forskolin resulted in a $3 \cdot 5$-fold stimulation of $a k r 1 b 7$ mRNA accumulation (Fig. 2A). Accordingly, the stimulating effect of hCG was reduced with $0 \cdot 2 \mu \mathrm{M}$ and completely abolished with $0.5 \mu \mathrm{M}$ H89, further indicating that hCG-stimulated expression of $a k r 1 b 7$ was mediated by the cAMP/PKA pathway. To provide evidence on the transcriptional regulation of the $a k r 1 b 7$ gene in response to hCG, MA-10 cells were incubated in the presence or absence of the transcription inhibitor actinomycin D (Fig. 2B). When treated with hCG alone, cells accumulated large amounts of akr1b7 mRNA. The presence of actinomycin $\mathrm{D}$ in the medium completely abolished this accumulation, thus indicating that the main control level of hCG on the akr $1 b 7$ gene expression takes place at the transcriptional level.
A

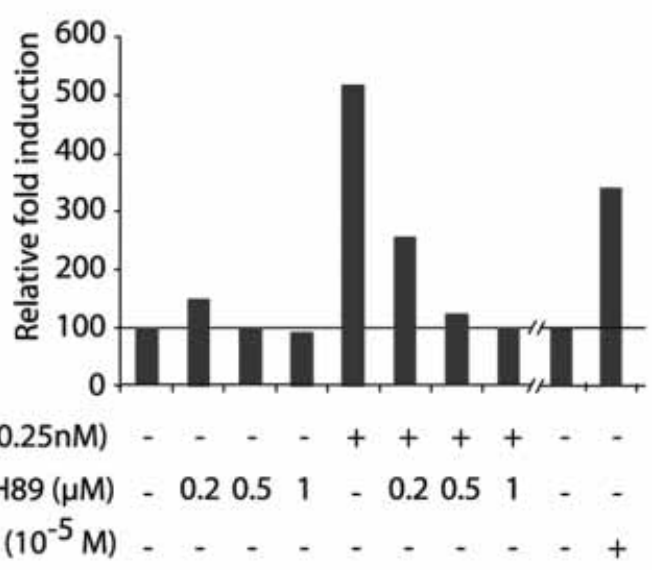

$a k r 1 b 7$

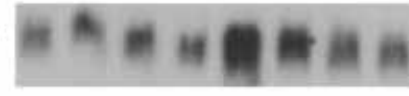

$\beta$-Actin
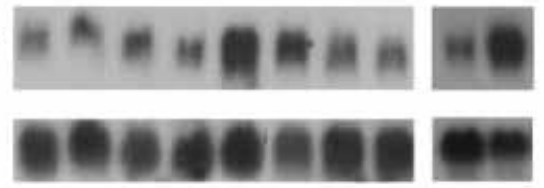

B

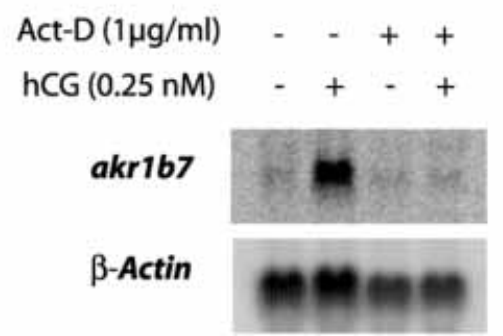

Figure 2 Effects of $\mathrm{H} 89$ and forskolin on akr1b7 levels in MA-10 cells. MA-10 cells were incubated for $1 \mathrm{~h}$ in the presence or absence of increasing concentrations of $(A)$ the PKA inhibitor $\mathrm{H} 89$ or $(B) 1 \mu \mathrm{g} / \mathrm{ml}$ actinomycin $\mathrm{D}$ (Act-D) before treatment with or without $0.25 \mathrm{nM} \mathrm{hCG}$ or $10 \mu \mathrm{M}$ forskolin (an adenylate cyclase activator) for $6 \mathrm{~h}$. Total cytoplasmic RNAs were isolated as described in Materials and methods, subjected to Northern blot analysis and hybridized sequentially with $a k r 1 b 7$ and $\beta$-actin cDNA probes. The blots presented are representative of three independent experiments.

\section{hCG induces akr1b7 expression in primary Leydig cells}

To assess the physiological relevance of the effects observed with the murine Leydig tumor cells MA-10, hCG induction of akr1b7 expression was analyzed in enriched mouse primary Leydig cell cultures. The results summarized in Fig. 3A 
A

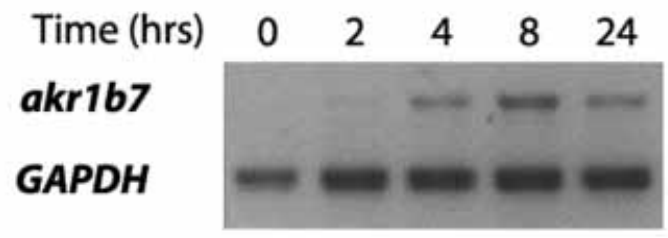

B

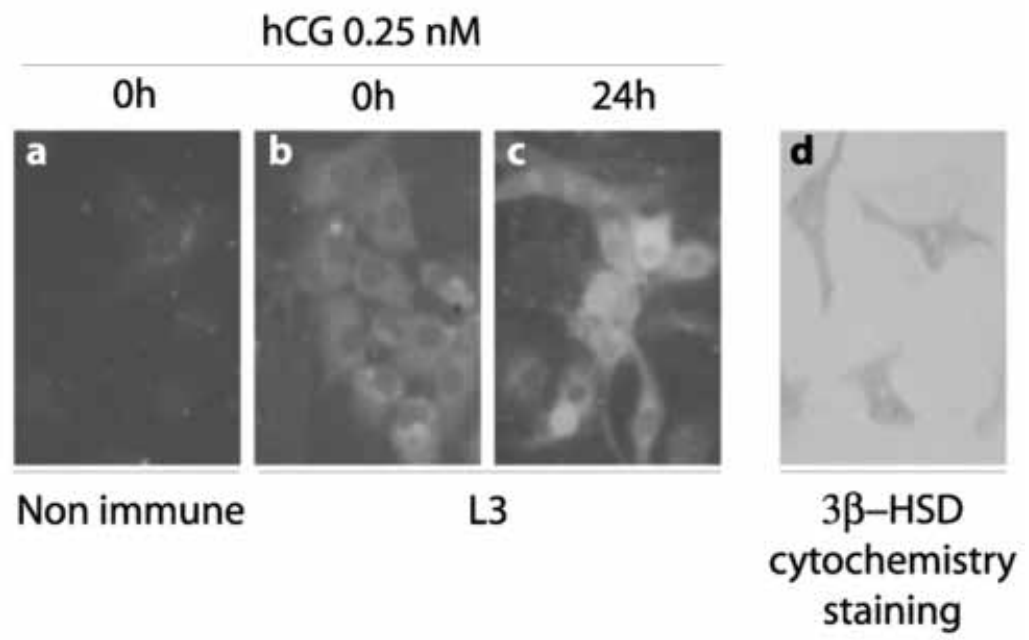

Figure 3 Expression of $a k r 1 b 7$ is hCG sensitive in primary mouse Leydig cells culture. (A) Primary mouse Leydig cells were incubated with $0.25 \mathrm{nM}$ hCG for 2-24 h. akr1b7 mRNA accumulation was analysed by semi-quantitative RT-PCR as described in Materials and methods. Co-amplification of GAPDH was performed as a standard. The blot presented is representative of three independent experiments. (B) Immunocytodetection of AKR1B7 was performed on primary Leydig cells incubated in the presence (c) or absence (a and b) of $0.25 \mathrm{nM} \mathrm{hCG}$ for $24 \mathrm{~h}$ using either L3 antibody (1/100) (b and c) or non-immune serum $(1 / 100)$ (a) revealed with FITC secondary antibody (1/150). Leydig cells were identified by $3 \beta-H S D$ cytochemical staining (d), as described in Materials and methods.

represent the time-dependent increase in steadystate levels of $a k r 1 b 7$ in response to $0 \cdot 25 \mathrm{nM} \mathrm{hCG}$. $a k r 1 b 7$ transcripts were detected from $4 \mathrm{~h}$ of induction and the magnitude of the response was maximal at $8 \mathrm{~h}$. The mRNA levels decreased slowly thereafter. Immunocytochemistry was performed directly on pubertal mouse primary cultured Leydig cells with immune rabbit serum directed against AKR1B7. The Leydig cells were distinguished from contaminating cells by their cytochemical staining for $3 \beta-H S D$ staining. Leydig cells exhibited positive fluorescence strictly limited to the cytoplasm and it was strongly enhanced after $24 \mathrm{~h}$ of hCG treatment (Fig. 3B). Specificity for AKR1B7 immunostaining was evident by the absence of reactivity when the primary antibody was omitted. Taken together, these results clearly demonstrated that akr $1 b 7$ 
expression is under $\mathrm{LH} / \mathrm{hCG}$ control in primary Leydig cells.

\section{The $a k r 1 b 7$ gene is developmentally expressed in testes}

In the mouse, histologic differentiation of the fetal Leydig cells occurs at E12 and testosterone formation begins shortly after (E12.5) (O'Shaughnessy et al. 1998). To determine the pattern of expression of the $a k r 1 b 7$ gene, RNA was extracted from testes isolated from mice at various embryonic and postnatal stages and analyzed by Northern blot (Fig. 4) and RT-PGR (data not shown). On E16.5, the earliest age tested, akr1b7 transcripts were very faintly detected. Thereafter, these levels increased sharply and reached a peak on day 6, before declining at day 10 and returning to basal levels at day 16 (Fig. 4A and C). The akr1b7 mRNA levels were higher in the early postnatal period than at adulthood. Western blot analysis revealed that the protein accumulation pattern was clearly different from that of mRNA. Even though detectable at E16·5, AKR1B7 levels strongly increased from day 3, reaching a maximum at day 20 (Fig. 4B and C) and remained high during adulthood. Akr1b7 mRNA and protein levels increased during fetal and perinatal life, but only protein accumulation was retained after 10 days of age when mRNA levels were dramatically reduced. The very low mRNA accumulation at adulthood is specific to $a k r 1 b 7$ since it was not observed for steroidogenic enzymes such as P450 scc and cytochrome P450 17 $\alpha$-hydroxylase (P450c17) (data not shown).

\section{Discussion}

The restricted expression of the P450 scc gene to steroidogenic tissues determines whether a cell is capable of converting cholesterol to pregnenolone (Miller 1988). The role of AKR1B7, which acts as a major reductase for isocaproaldehyde, a product of side-chain cleavage of cholesterol generated during steroidogenesis, suggests a similar pattern of expression. Studies from our own and other laboratories have demonstrated that AKR1B7 is expressed in adrenals and ovaries (Lau et al. 1995, Aigueperse et al. 1999, Brockstedt et al. 2000). The bulk of steroid hormone synthesis in the testis is confined to the Leydig cells. This report describes, for the first time, the expression of the $a k r 1 b 7$ gene in both the MA-10 tumor cell line and primary cultures of mouse Leydig cells. Initial studies revealed the cell-type specificity of $a k r 1 b 7$ expression within the ovary and the adrenal gland. Immunohistochemical studies have shown that AKR1B7 was detected only in the cells of the zona fasciculata in adrenals (Aigueperse et al. 1999). In the ovary, in situ hybridization localized akr1b7 mRNA to thecal and interstitial cells (Brockstedt et al. 2000). This distribution in adrenals and gonads was expected, considering the function of the protein in detoxifying isocaproaldehyde. However, it has been reported that not all of the steroidogenically active cells showed $a k r 1 b 7$ expression since the products of the gene were undetectable in the zona glomerulosa and zona reticularis in adrenals (Aigueperse et al. 1999) and in the corpus luteum (Brockstedt et al. 2000). Previous results have demonstrated that aldose reductase AKR1B1 has the ability to reduce isocaproaldehyde (Matsuura et al. 1996). The expression of aldose reductase in adrenals (Inazu et al. 1994) and rat granulosa cells (Iwata et al. 1996) suggested a role in reducing isocaproaldehyde, especially in steroidogenic cells which were devoid of AKR1B7.

The endocrine regulation of Leydig cells occurred predominantly through the LH/hCG receptor after coupling to the adenylate cyclase signal transduction pathway. The present study shows that akr1b7 mRNA and protein levels were increased in response to hCG stimulation in a timeand dose-dependent manner in MA-10 mouse Leydig tumor cells. Accordingly, hGG significantly increased $a k r 1 b 7$ expression in a primary culture of adult mouse Leydig cells. The hCG-induced akr1b7 gene expression was abolished following treatment of MA-10 cells with the PKA inhibitor H89, indicating a critical role of the PKA signaling pathway in regulating akrlb7 expression in the Leydig cells. Moreover, forskolin, an activator of adenylate cyclase, mimicked the hCG-induced $a k r 1 b 7$ mRNA accumulation. This is in agreement with results showing that cAMP is an inducer of $a k r 1 b 7$ gene expression in specific steroidogenic cells within the adrenals and ovaries. When given acutely, LH increased testosterone synthesis within 30 min by enhancing the transport of cholesterol to the inner mitochondrial membrane and its association with $\mathrm{P} 450$ scc. In the steady state, LH 
A

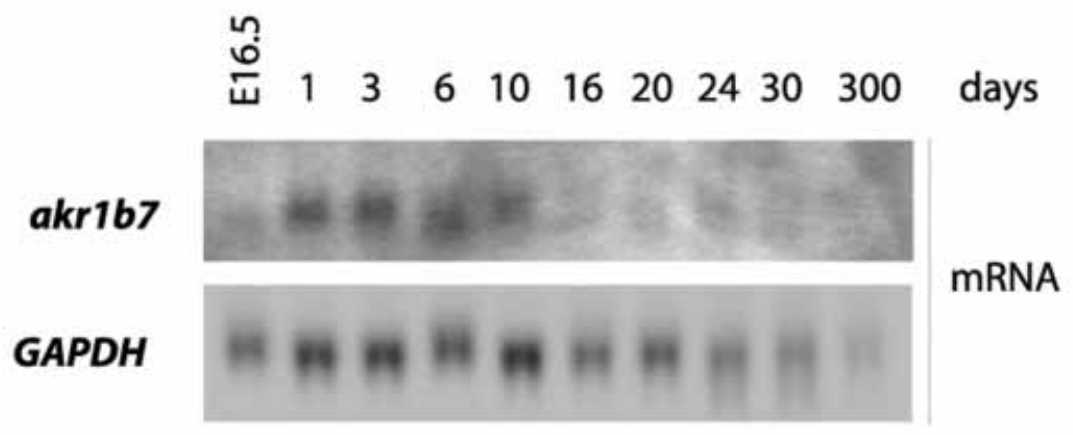

B

$$
\begin{array}{lllllllll}
\frac{\mathfrak{6}}{4} & 1 & 3 & 10 & 20 & 24 & 30 & 300 & \text { days }
\end{array}
$$

AKR1B7

B-ACTIN

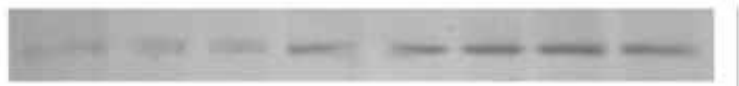

protein

C

AKR1B7 protein $a k r 1 b 7$ mRNA

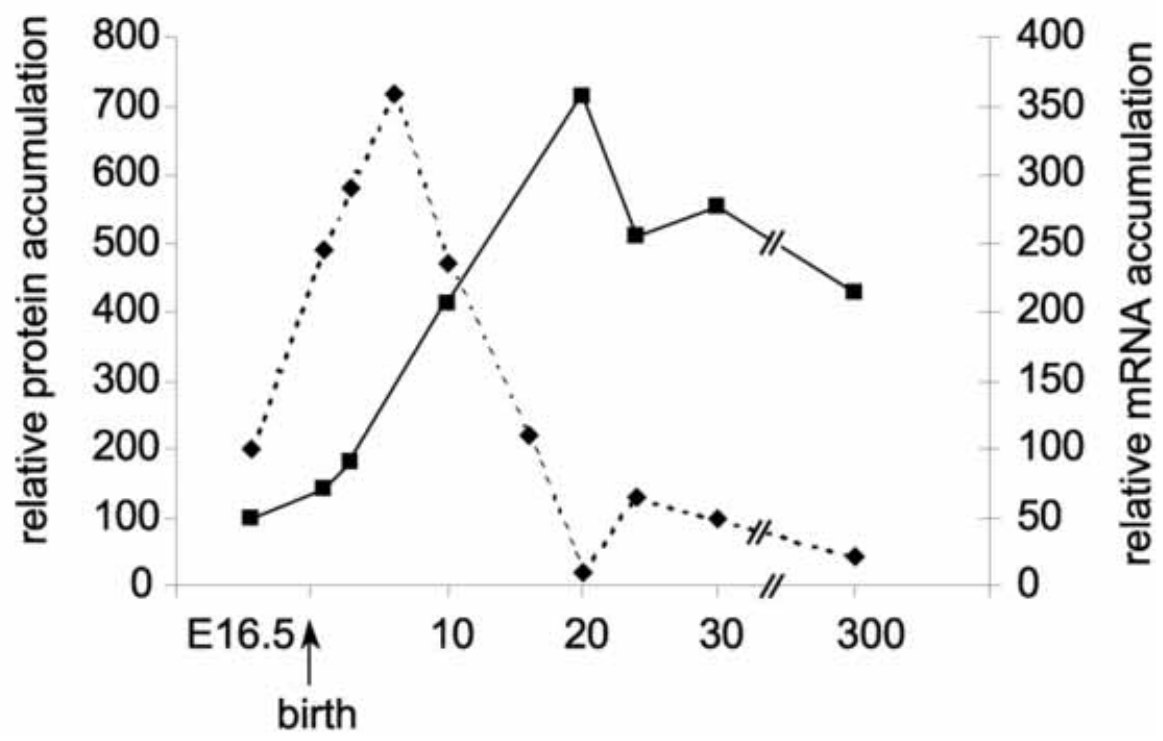


stimulated testosterone synthesis by increasing transcription of the P450 scc gene and other genes involved in the pathway (Miller 1988). The transcripts of the $a k r 1 b 7$ gene were first detected $2 \mathrm{~h}$ after hCG treatment and their accumulation was sensitive to the transcription inhibitor actinomycin $\mathrm{D}$, suggesting a relatively early transcriptional regulation. Interestingly, the results showed that expression of both akr1b7 and P450 scc genes, the products of which are involved in the first step in steroidogenesis, appeared temporally co-ordinated by LH/hCG in Leydig cells. Similar results have been reported in adrenals (Aigueperse et al. 2001), suggesting that co-ordinated expression of both genes is physiologically important and providing evidence that they are linked to a common regulatory cascade. The transcription of steroid hydroxylase genes, including P450 scc, are controlled in the adrenals by ACTH via cAMP. However, each gene utilizes its own unique cAMP-responsive system (Waterman 1994). Functional analyzes of the 5 '-flanking regions have revealed that cAMP-dependent transcriptional regulation of bovine $P 450$ scc gene was mediated by steroidogenic factor-1 (SF1) plus specific promoter factor-1 (Liu \& Simpson 1997). The orphan nuclear receptor SF1 is a key regulator of other different steroidogenic genes (Parker \& Schimmer 1997). SF1 presents a limited tissue distribution and recognizes a conserved regulatory region consensus site in the proximal promoter of a number of these genes (Morohashi 1999). It was previously reported that the SF1 protein interacts specifically with a non-canonical regulatory element located in the downstream half site of an androgen response element within the promoter of $a k r 1 b 7$ (Aigueperse et al. 2001). However, SF1 regulates the basal level of $a k r 1 b 7$ gene expression while SP1 and $\beta$ CGAAT/enhancer binding protein are required for cAMP responsiveness in murine adrenocortical cells (Aigueperse et al. 2001). The molecular mechanisms involved in the regulation of $a \mathrm{kr} 1 \mathrm{b7}$ expression in Leydig cells remain to be determined.
There was an increase in akr1b7 mRNA levels from E15 to the day of birth and a decline thereafter. In the mouse testis, P450 scc mRNA accumulation followed a similar pattern from E15 to day 5 (O'Shaughnessy et al. 1998). This temporal coincidence suggested that expression of both genes was developmentally co-ordinated during fetal and perinatal life. Mice with destruction of the fetal hypophysis (Raynaud \& Frilley 1947) or disruption of the common pituitary $\alpha$-subunit (Kendall et al. 1995) showed a normal male phenotype at birth, indicating that production of androgens by the fetal testis is pituitary independent. In hypogonadal mice, which lack gonadotropin-releasing hormone and thus gonadotropins, levels of mRNA encoding P450 scc and P450c17 were normal until birth (O'Shaughnessy et al. 1998). These observations suggested that either akr1b7 was constitutively expressed during fetal testicular development, or that factors other than LH induced its transcription. Since the placenta does not secrete gonadotropins in rodents (Tepper \& Roberts 1984), paracrine factors such as growth factors and cytokines might be involved as regulators of Leydig cell function (Lejeune et al. 1998). The maximal levels of $a k r 1 b 7$ and P450 scc mRNAs, measured at day 1 , coincide with a serum gonadotropin and testosterone surge which occurs during the first few hours after birth in rodents (Corbier et al. 1978). The decrease observed in akr1b7 mRNA levels after day 3 was perhaps related to the prepubertal regression of Leydig cells (Gondos 1980) and an associated decline in testosterone production (Jean-Faucher et al. 1978). Surprisingly, akr1b7 mRNA levels remained low in males aged 30 and 45 days despite the rise in plasma $\mathrm{LH}$ and the increased testicular responsiveness which occurred between 20 and 40 days (Jean-Faucher et al. 1983a,b). AKR1B7 protein exhibited an inverse developmental pattern with levels increasing until adulthood, indicating that regulation of mRNA translation is an important aspect of the control of $a k r 1 b 7$ expression. The data suggested that an

Figure $4 a k r 1 b 7$ mRNA and protein accumulation during mouse development. (A) Total RNA from testes of animals killed at different developmental stages were subjected to Northern blot analysis and hybridized sequentially with akr1b7 and $\beta$-actin cDNA probes. (B) Total cytoplasmic proteins were isolated as described in Materials and methods, and were separated by SDS-PAGE migration and subjected to Western blot analysis. Immunodetection was performed with the L3 antibody. The relative accumulation of akr1b7 mRNA and protein during development is shown in $(C)$. These results are representative of two independent experiments. 
increase in translational efficiency, occurring during sexual maturation, allowed high AKR1B7 protein expression in the presence of decreasing mRNA levels. There was not always a correlation between the levels of mRNA and protein in steroidogenic enzyme expression processes. In the adrenals of rats which had received ACTH for 9 days, the levels of P450 ssc mRNA were unchanged whereas its protein concentration was significantly increased (Lehoux et al. 1998). Interestingly, LH receptor mRNA level was lower in adult than in immature rat Leydig cells, whereas $\left[{ }^{125} \Gamma \mathrm{hCG}\right.$ binding was higher in the former (Shan \& Hardy 1992). Translation rates are modulated in response to growth factors, hormones and mitogens. Leydig cell function is also under paracrine control in vivo. The importance of such paracrine effects is supported by the differential akr $1 b 7$ expression control in adult primary culture cells and in the testis. It has also been shown that growth factors might increase gonadotropin-stimulated testosterone production (Lejeune et al. 1998). Further experiments need to be carried out to identify the factors and mechanisms responsible for the changes observed in the translational efficiency of $a k r 1 b 7$ mRNA in the testis.

\section{Acknowledgements}

We are grateful to Drs A Martinez and A-M Lefrançois-Martinez for fruitful and constructive discussions and to Drs M Begeot and M Vigier (INSERM-INRA U418, Lyon, France) for the development of primary Leydig cell cultures. We also thank J P Saru and D Cheyvialle for technical assistance.

\section{References}

Aigueperse C, Martinez A, Lefrancois-Martinez AM, Veyssiere G \& Jean CI 1999 Cyclic AMP regulates expression of the gene coding for a mouse vas deferens protein related to the aldo-keto reductase superfamily in human and murine adrenocortical cells. Fournal of Endocrinology 160 147-154.

Aigueperse C, Val P, Pacot C, Darne C, Lalli E, Sassone-Corsi P, Veyssiere G, Jean C \& Martinez A 2001 SF-1 (steroidogenic factor-1), C/EBPbeta (CCAAT/enhancer binding protein), and ubiquitous transcription factors NF1 (nuclear factor 1) and Spl (selective promoter factor 1) are required for regulation of the mouse aldose reductase-like gene (AKR1B7) expression in adrenocortical cells. Molecular Endocrinology 15 93-111.

Ascoli M 1981 Characterization of several clonal lines of cultured Leydig tumor cells: gonadotropin receptors and steroidogenic responses. Endocrinology 108 88-95.
Brockstedt E, Peters-Kottig M, Badock V, Hegele-Hartung C \& Lessl M 2000 Luteinizing hormone induces mouse vas deferens protein expression in the murine ovary. Endocrinology 141 2574-2581.

Corbier P, Kerdelhue B, Picon R \& Roffi J 1978 Changes in testicular weight and serum gonadotropin and testosterone levels before, during, and after birth in the perinatal rat. Endocrinology 103 1985-1991.

Darne CH, Morel L, Claessens F, Manin M, Fabre S, Veyssiere G, Rombauts W \& Jean CL 1997 Ubiquitous transcription factors $\mathrm{NF} 1$ and $\mathrm{Sp} 1$ are involved in the androgen activation of the mouse vas deferens protein promoter. Molecular and Cellular Endocrinology 132 13-23.

Fabre S, Manin M, Pailhoux E, Veyssiere G \& Jean C 1994 Identification of a functional androgen response element in the promoter of the gene for the androgen-regulated aldose reductase-like protein specific to the mouse vas deferens. Fournal of Biological Chemistry 269 5857-5864.

Gondos B 1980 Development and differentiation of the testis and male reproductive tract. In Testicular Development, Structure and Function, pp 3-20. Eds A Steinberger \& B Steinberger. New York: Raven Press.

Hanukoglu I, Feuchtwanger R \& Hanukoglu A 1990 Mechanism of corticotropin and cAMP induction of mitochondrial cytochrome P450 system enzymes in adrenal cortex cells. Fournal of Biological Chemistry 265 20602-20608.

Inazu N, Nagashima Y, Satoh T \& Fujii T 1994 Purification and properties of six aldo-keto reductases from rat adrenal gland. Fournal of Biochemistry 115 991-999.

Iwata N, Hara S, Nishimura C, Takahashi M, Mukai T, Takayama M \& Endo T 1996 Hormonal regulation of aldose reductase in rat ovary during the estrous cycle. European Fournal of Biochemistry $235444-448$.

Jean-Faucher C, Berger M, de Turckheim M, Veyssiere G \& Jean C 1978 Developmental patterns of plasma and testicular testosterone in mice from birth to adulthood. Acta Endocrinologica 89 780-788.

Jean-Faucher C, Berger M, de Turckheim M, Veyssiere G \& Jean C $1983 a$ Testicular response to HCG stimulation and sexual maturation in mice. Hormone Research 17 216-221.

Jean-Faucher C, El Watik N, Berger M, de Turckheim M, Veyssiere G \& Jean C 1983b Ontogeny of the secretory pattern of LH and $\mathrm{FSH}$ in male mice during sexual maturation. International fournal of Andrology 6 575-584.

Jez JM, Bennett MJ, Schlegel BP, Lewis M \& Penning TM 1997 Comparative anatomy of the aldo-keto reductase superfamily. Biochemical fournal 326 625-636.

Kendall SK, Samuelson LC, Saunders TL, Wood RI \& Camper SA 1995 Targeted disruption of the pituitary glycoprotein hormone alpha-subunit produces hypogonadal and hypothyroid mice. Genes and Development 9 2007-2019.

Lau ET, Cao D, Lin C, Chung SK \& Chung SS 1995 Tissuespecific expression of two aldose reductase-like genes in mice: abundant expression of mouse vas deferens protein and fibroblast growth factor-regulated protein in the adrenal gland. Biochemical fournal 312 609-615.

Lefevre A, Saez JM \& Finaz C 1983 hCG responsiveness of purified Leydig cells from immature and mature rats. Hormone Research $\mathbf{1 7}$ $114-120$

Lefrancois-Martinez AM, Tournaire G, Martinez A, Berger M, Daoudal S, Tritsch D, Veyssiere G \& Jean C 1999 Product of side-chain cleavage of cholesterol, isocaproaldehyde, is an endogenous specific substrate of mouse vas deferens protein, an aldose reductase-like protein in adrenocortical cells. Fournal of Biological Chemistry 274 32875-32880.

Lehoux JG, Fleury A \& Ducharme L 1998 The acute and chronic effects of adrenocorticotropin on the levels of messenger 
ribonucleic acid and protein of steroidogenic enzymes in rat adrenal in vivo. Endocrinology 139 3913-3922.

Lejeune H, Habert R \& Saez JM 1998 Origin, proliferation and differentiation of Leydig cells. Fournal of Molecular Endocrinology 20 $1-25$.

Liu Z \& Simpson ER 1997 Steroidogenic factor 1 (SF-1) and SP1 are required for regulation of bovine CYP11A gene expression in bovine luteal cells and adrenal Y1 cells. Molecular Endocrinology 11 127-137.

Martinez A, Pailhoux E, Berger M \& Jean C 1990 Androgen regulation of the mRNA encoding a major protein of the mouse vas deferens. Molecular and Cellular Endocrinology 72 201-211.

Matsuura K, Deyashiki Y, Bunai Y, Ohya I \& Hara A 1996 Aldose reductase is a major reductase for isocaproaldehyde, a product of side-chain cleavage of cholesterol, in human and animal adrenal glands. Archives of Biochemistry and Biophysics 328 265-271.

Miller WL 1988 Molecular biology of steroid hormone synthesis. Endocrine Reviews 9 295-318.

Morohashi KI 1999 Gonadal and extragonadal functions of Ad4 BP/SF-1: developmental aspects. Trends in Endocrinology and Metabolism 10 169-173.

O’Shaughnessy PJ, Baker P, Sohnius U, Haavisto AM, Charlton HM \& Huhtaniemi I 1998 Fetal development of Leydig cell activity in the mouse is independent of pituitary gonadotroph function. Endocrinology 139 1141-1146.

Pailhoux EA, Martinez A, Veyssiere GM \& Jean CG 1990 Androgen-dependent protein from mouse vas deferens. cDNA cloning and protein homology with the aldo-keto reductase superfamily. Fournal of Biological Chemistry 265 19932-19936.

Papadopoulos V 1998 Structure and function of the peripheral-type benzodiazepine receptor in steroidogenic cells. Proceedings of the Society for Experimental Biology and Medicine 217 130-142.

Parker KL \& Schimmer BP 1997 Steroidogenic factor 1: a key determinant of endocrine development and function. Endocrine Reviews 18 361-377.

Payne AH, Downing JR \& Wong KL 1980 Luteinizing hormone receptors and testosterone synthesis in two distinct populations of Leydig cells. Endocrinology 106 1424-1429.
Privalle GT, Crivello JF \& Jefcoate CR 1983 Regulation of intramitochondrial cholesterol transfer to side-chain cleavage cytochrome P-450 in rat adrenal gland. PNAS 80 $702-706$.

Raynaud A \& Frilley M 1947 Developpement intra utérin des embryons de souris dont les ébauches de l'hypophyse ont été détruites au moyen des rayons X au 13è me jour de gestation. Comptes Rendus de l'Academie des Sciences 225 596-598.

Shan LX \& Hardy MP 1992 Developmental changes in levels of luteinizing hormone receptor and androgen receptor in rat Leydig cells. Endocrinology 131 1107-1114.

Simpson ER \& Waterman MR 1988 Regulation of the synthesis of steroidogenic enzymes in adrenal cortical cells by ACTH. Annual Review of Physiology $\mathbf{5 0}$ 427-440.

Stocco DM \& Clark BJ 1997 The role of the steroidogenic acute regulatory protein in steroidogenesis. Steroids 62 29-36.

Taragnat C, Berger M \& Jean C 1988 Preliminary characterization, androgen-dependence and ontogeny of an abundant protein from mouse vas deferens. Fournal of Reproduction and Fertility $\mathbf{8 3}$ 835-842.

Taragnat C, Berger M \& Jean CL 1990 Tissue and species specificity of mouse ductus deferens protein. Fournal of Andrology 11 279-286.

Tepper MA \& Roberts JL 1984 Evidence for only one betaluteinizing hormone and no beta-chorionic gonadotropin gene in the rat. Endocrinology 115 385-391.

Val P, Martinez A, Sahut-Barnola I, Jean C, Veyssiere G \& Lefrancois-Martinez AM 2002 A 77-base pair LINE-like sequence elicits androgen-dependent mvdp/akrl-b7 expression in mouse vas deferens, but is dispensable for adrenal expression in rats. Endocrinology 143 3435-3448.

Waterman MR 1994 Biochemical diversity of cAMP-dependent transcription of steroid hydroxylase genes in the adrenal cortex. Fournal of Biological Chemistry 269 27783-27786.

Received 7 March 2003

Accepted 23 April 2003 